\title{
EM1 pyroxenite melts from the SCLM: a possible source of the enriched isotope signatures in Andean NSVZ arc magmas
}

\author{
NINA SØAGER ${ }^{1}$, PAUL MARTIN HOLM ${ }^{1}$ AND KAJ \\ HOERNLE $^{2}$ \\ ${ }^{1}$ University of Copenhagen \\ ${ }^{2}$ GEOMAR Helmholtz Centre for Ocean Research Kiel \\ Presenting Author: ns@ign.ku.dk
}

The source of the isotopic and elemental enrichment of the Andean Northern Southern Volcanic Zone (NSVZ) arc magmas is a topic of continuing debate where lithospheric assimilation and subduction erosion (crustal and/or mantle) are the prevailing hypotheses. Major element compositions of new mafic samples from the rear-arc of the NSVZ fall into two groups, both with high $\mathrm{Mg} \#(68-72)$ but distinct $\mathrm{CaO}, \sim 7.7$ and $\sim 9.0$ wt.\%, respectively. Olivine compositions with Fo $>86$ from the two groups indicate that the high-Ca magmas are dominated by peridotite melts (intermediate $\mathrm{Ni} * \mathrm{FeO} / \mathrm{MgO}$ and $\mathrm{Fe} / \mathrm{Mn}$ and high $\mathrm{Mn} / \mathrm{Zn}$ relative to global olivine trends) similar to Fo-rich olivines from the Maipo volcano and other SVZ rocks. In contrast, the low-Ca group olivines display a large variation indicating mixing between peridotite and pyroxenite melts (with $\mathrm{Ni} * \mathrm{FeO} / \mathrm{MgO}$ up to $970, \mathrm{Fe} / \mathrm{Mn}$ up to 83 and $\mathrm{Mn} / \mathrm{Zn}$ down to 9 ). $\mathrm{Mn} / \mathrm{Zn}$ is positively correlated with magma temperature (1020$1125^{\circ} \mathrm{C}$ ) and negatively with $f \mathrm{O}_{2}(\triangle \mathrm{QFM} 0.5-2.1$ ) (based on olivine-spinel methods) suggesting that the pyroxenite melts are colder and more oxidised than the peridotite melts. The pyroxenite melt derived olivines are significantly higher in $\mathrm{Ti}$, $\mathrm{Li}, \mathrm{P}$ and $\mathrm{Zn}$ and have up to three times higher $\mathrm{Cu}$-contents and must have crystallized from distinctly more enriched melts than the normal arc melts. Furthermore, the olivines of the low-Ca group have low Fo rims (down to $\mathrm{Fo}_{75}$ ) with high $\mathrm{Cu}$ (up to 11 $\mathrm{ppm}$ ) whereas low-Fo olivines from the Maipo volcano have low $\mathrm{Cu} \sim 2$ ppm due to early sulfide saturation of these magmas. The whole rocks have characteristic $\mathrm{Sr}-\mathrm{Nd}$ isotope signatures of the NSVZ but less radiogenic EM1-like $\mathrm{Pb}$ isotopes. This isotopic signature rules out melange rocks as source of the pyroxenite melts. Instead, we suggest that the pyroxenite melts are derived from enriched lithospheric mantle of the Proterozoic basement and that such melts could be the source of the unusually enriched NSVZ isotopic signatures. However, the larger slab flux in the main NSVZ arc magmas can explain their higher $\mathrm{Pb}$-isotopes. 